\title{
The Production Potential of the Agroindustrial Complex of the Siberian Federal District - the Basis for the Development of the Food Market of the Region
}

\author{
Yulia Yu. Suslova and Andrey V. Voloshin* \\ Siberian Federal University \\ 79 Svobodny, Krasnoyarsk, 660041, Russia
}

Received 05.05.2017, received in revised form 31.10.2017, accepted 07.11.2017

This article analyzes production of the core types of agricultural products by the regions of the Siberian Federal District. In particular, the structure of crop areas of cereals, including wheat, oilbearing crops, such as sunflower, field vegetables and potatoes in the farms of all categories in the Federal District regions are analyzed. The structure of the number of cattle, the production of meat, poultry, butter, cheese, milk, eggs, flour and grains of various types are analyzed separately.

The studies of the production of agricultural products per capita according to the above crops and livestock products are carried out as well, the main trends and patterns in product balance and the structure of production and processing by the Siberian Federal District regions are revealed.

Keywords: agriculture, agribusiness, production and processing of agricultural products, the demand for crop products and livestock.

DOI: 10.17516/1997-1370-0173.

Research area: economics.

The dynamics of the economic development of the Siberian Federal District, the necessity to meet the needs of the population of the Region and the country in agricultural products determine the importance of the agro-industrial complex in the context of food security and import substitution.

Ranking by the volumes of agricultural production of the Subjects of the Federation that are in the Siberian Federal District allows to identify a group of leaders: the Altai Krai (20.9\%), the Omsk Oblast (15.4\%), the Krasnoyarsk Krai (14.6\%), the Novosibirsk Oblast (13.1\%) and the Irkutsk Oblast (10.4\%). The aforementioned regions together form more than $70 \%$ of the volume of agricultural production in the District and are the basis of the agricultural industry of Siberia (Fig. 1).

Analysis of the structure of agricultural production shows a lower share of agricultural organizations $(41.8 \%$ ), a higher proportion of households $(49.3 \%)$ and a low proportion of peasant (farm) households ( $8.9 \%$ ) in comparison with the Russian Federation as a whole, the same values for the country are $49.5 \%, 40.5 \%$, $10.0 \%$, respectively. Within the Federal District, the Republic of Altai (24.4\%), the Republic of

(C) Siberian Federal University. All rights reserved

* Corresponding author E-mail address: sokol-151@yandex.ru; a_voloshin2010@hotmail.com 
Khakassia (14.8\%), the Omsk Oblast (14.1\%) and the Altai Krai (10.0\%) occupy a predominant position in the share of farm households. In the Krasnoyarsk Krai, for comparison, the value of this indicator is $3.7 \%$, and the largest share in the structure of the agricultural production of the Region is occupied by the population's households $-56.0 \%$.

The structure of the cultivated areas of the basic agricultural crops reflects the structure of agricultural production. In general, the Siberian Federal District accounts for $21.7 \%$ of the area allocated for grain crops in the Russian Federation, including $25.4 \%$ of wheat areas, $1.9 \%$ of areas for sugar beets, $9.1 \%$ of areas for oil crops, including $8 \%$ of sunflower areas, $9 \%$ of field vegetables and $17.5 \%$ of potato areas. Within the District, the Altai Krai, the Omsk Oblast, the Novosibirsk Oblast and the Krasnoyarsk Krai occupy leading positions in cultivated areas, especially those designated for grain crops.

More clearly, the structure of cultivated areas for different crops in the SFD regions can be represented graphically in Figures 2-7.

Analysis of the use of cultivated areas allows making a conclusion that the obvious leader is the Altai Krai, which is rightly considered to be the main "breadbasket" of Siberia and its largest agro-industrial region. The Krasnoyarsk Krai is the leader in the cultivated areas for potatoes 72.6 thousand hectares, and is also among the top five leaders in field vegetables -8.9 thousand hectares and wheat -678.9 thousand hectares.

The number of cattle in the Siberian Federal District is $21.53 \%$ of the national value, including $20.92 \%$ of cow stock, $16.06 \%$ pig stock, and $15.35 \%$ of sheep and goat stock. Generally, the Altai Krai, the Omsk Oblast, the Novosibirsk Oblast, the Krasnoyarsk Krai, Zabaykalsky Krai and the Republic of Buryatia are the leaders in the major types of cattle. The Tuva Republic (30.21\%), the Altai Republic (16.7\%) and the Zabaykalsky Krai (13.25\%) have a somewhat different structure for the number of sheep and goat, and are the leaders in the livestock number.

The structure of the cattle number in the regions of the SFD can be graphically demonstrated in Figure 8.

The five regions of the Siberian Federal District that are leading in the cattle number are represented by the Altai Krai - 833.3 thousand heads, the Zabaykalsky Krai, the Krasnoyarsk Krai, the Novosibirsk Oblast and the Omsk Oblast, with more than 420 thousand heads in each region.

The presence of livestock number and cultivated areas in the regions of Siberia supposes local production and processing of

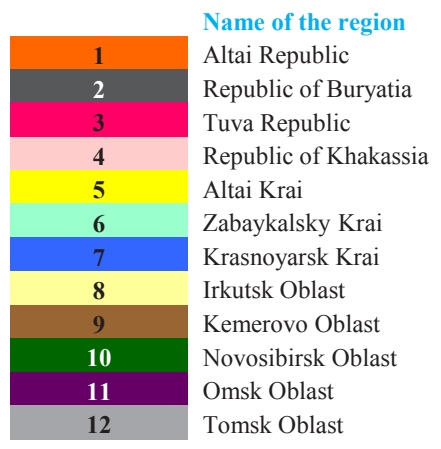

Ranking
11
9
12
10
1
8
3
5
6
4
2
7

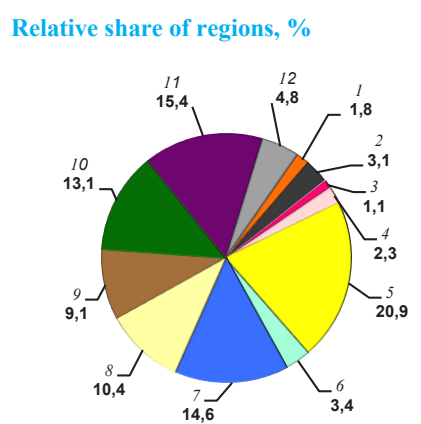

Fig. 1. Structure of agricultural products in the regions of the SFD (in households of all categories, in current prices), $\%$ 


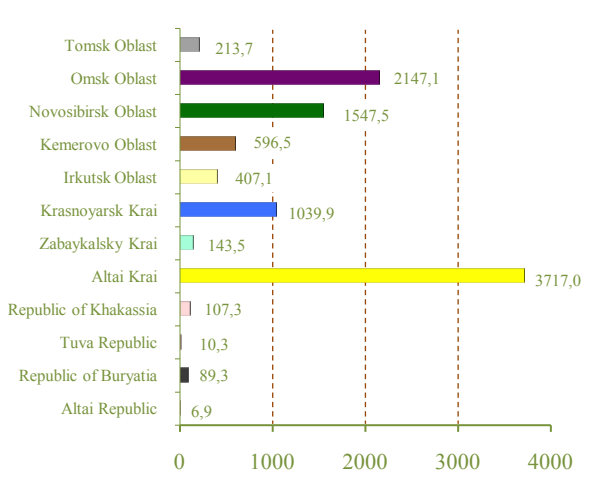

Fig. 2. The structure of the cultivated areas for grain crops in the regions of the SFD (in households of all categories, thousand hectares)

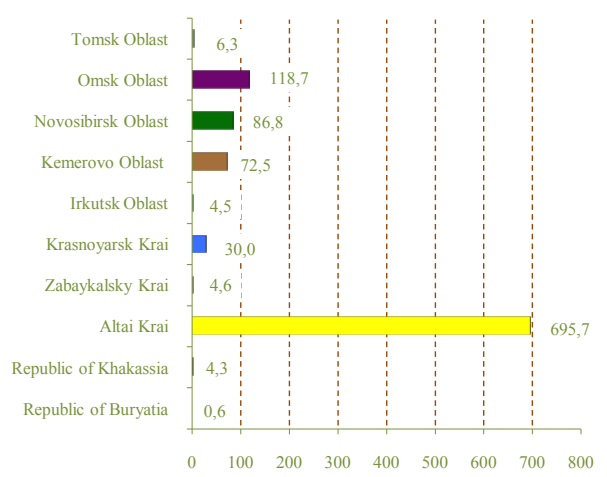

Fig. 4. The structure of the cultivated areas for oil crops in the regions of the SFD (in households of all categories, thousand hectares)

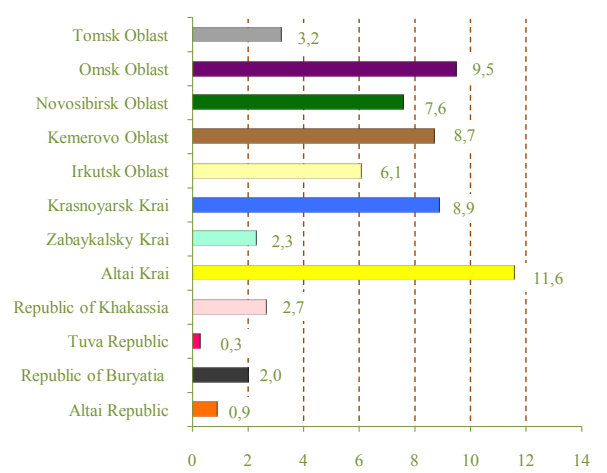

Fig. 6. The structure of the cultivated areas for field vegetables in the regions of the SFD (in households of all categories, thousand hectares)

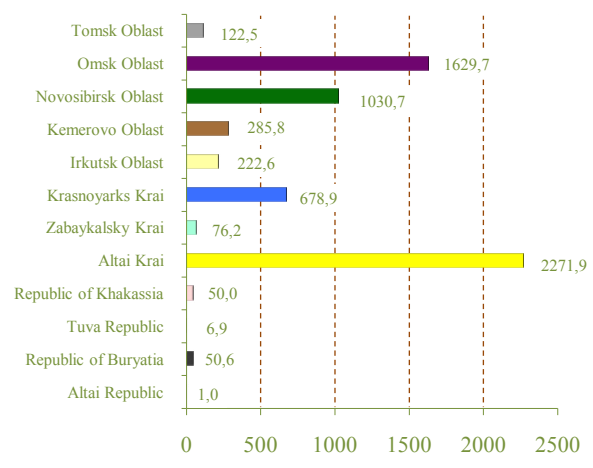

Fig. 3. The structure of the cultivated areas for wheat in the regions of the SFD (in households of all categories, thousand hectares)

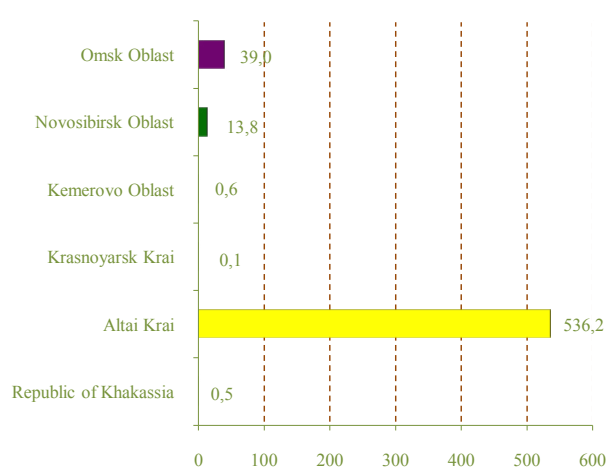

Fig. 5. The structure of the cultivated areas for sunflower in the regions of the SFD (in households of all categories, thousand hectares)

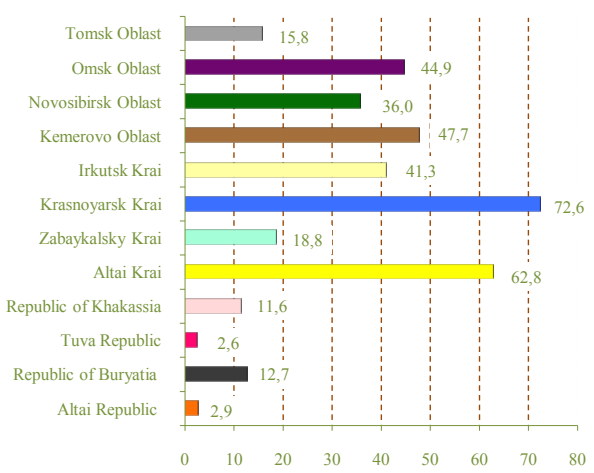

Fig. 7. The structure of the cultivated areas for potatoes in the regions of the SFD (in households of all categories, thousand hectares) 


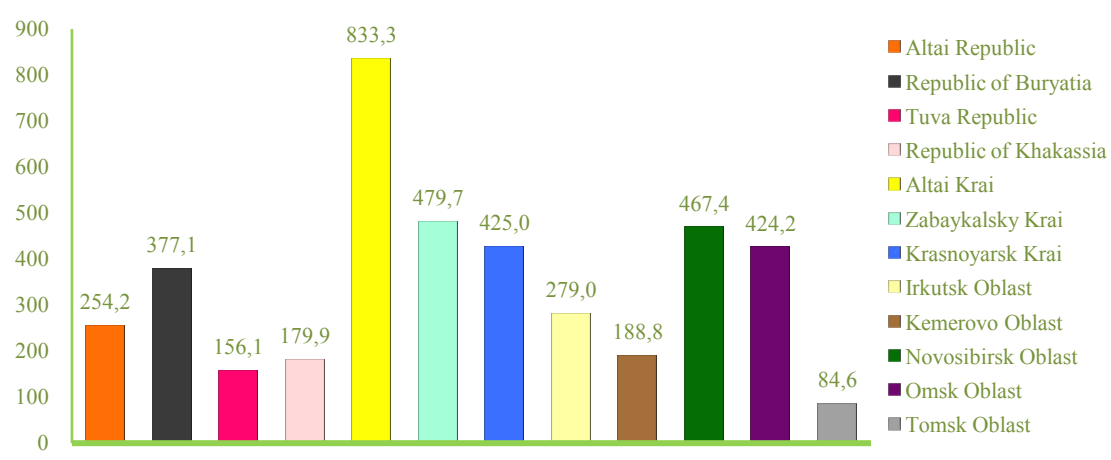

Fig. 8. The structure of livestock in the regions of the SFD (in farms of all categories at the end of the year, thousands of heads)

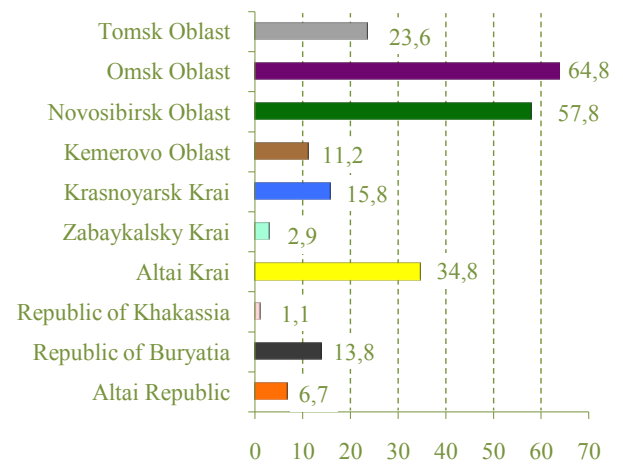

Fig. 9. The structure of production of meat and byproducts of the slaughter animals for food in the regions of the SFD, thousand tons

this raw material, which leads to the growth and development of the entire agro-industrial complex of Siberia, the availability of additional jobs, the use of modern technologies in agriculture and formation of the regions' profitability.

The structure of production of the main types of raw materials and food products is represented graphically in Figures 9-14.

The main leaders in production of meat and by-products of the slaughter animals are the Omsk Oblast -64.8 thousand tons, the Novosibirsk Oblast - 57.8 thousand tons and the Altai Krai 34.8 thousand tons (Fig. 9).

The main leaders in production of meat and by-products of poultry are the Altai Krai -66.8 thousand tons, the Tomsk Oblast -56.38 thousand

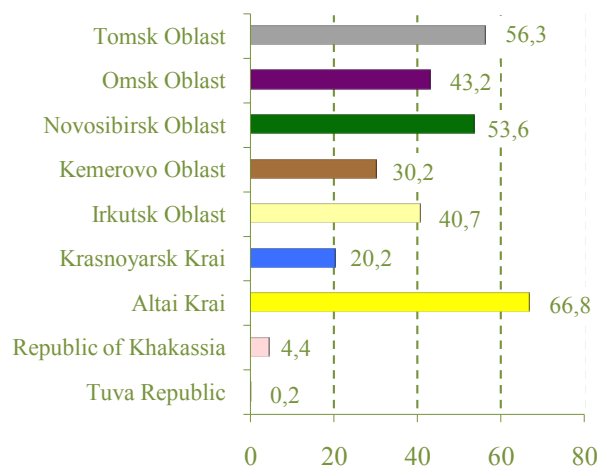

Fig. 10. The structure of production of meat and byproducts of poultry in the regions of the SFD, thousand tons

tons and the Novosibirsk Oblast -53.6 thousand tons (Fig. 10).

The main leaders in production of butter and butter pastes are the Altai Krai - 16.2 thousand tons, the Omsk Oblast -6.7 thousand tons and the Novosibirsk Oblast -4.5 thousand tons (Fig. 11).

The main leaders in production of cheese and cheese products are Altai Krai - 71.3 thousand tons and Omsk Oblast - 28.5 thousand tons (Fig. 12).

The main leader in production of cereals and wholemeal flour is the Altai Krai-283.4 thousand tons and the Omsk Oblast -51.1 thousand tons (Fig. 13).

The main leader in production of cereals flour, vegetable and plant crops, and mixed vegetables 


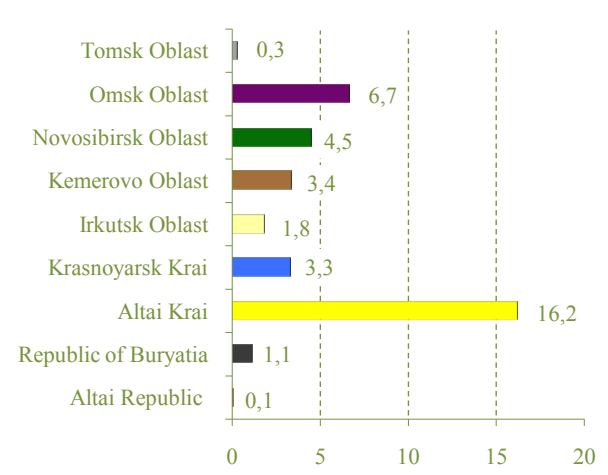

Fig. 11. The structure of production of butter and butter paste in the regions of the SFD, thousand tons

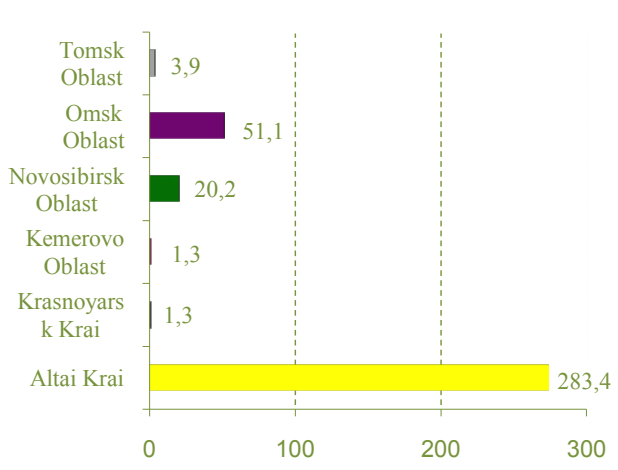

Fig. 13. The structure of production of flour and wholemeal flour in the regions of the SFD, thousand tons

is the Altai Krai - 1246.9 thousand tons and the Omsk Oblast - 366.4 thousand tons and the Krasnoyarsk Krai - 245.6 thousand tons (Fig. 14).

The analysis of production of the main crop and livestock products per capita in the context of the SFD regions is of the greatest interest for the study.

The analysis of the structure of the main crop products production per capita in the context of the regions of the SFD demonstrated that the production of grain and leguminous crops in the SFD in general is behind the indicators for the Russian Federation - 674 kg per capita, versus $721 \mathrm{~kg}$ in the country. In the Krasnoyarsk Krai the production is $773 \mathrm{~kg}$ per capita, which exceeds the national average.

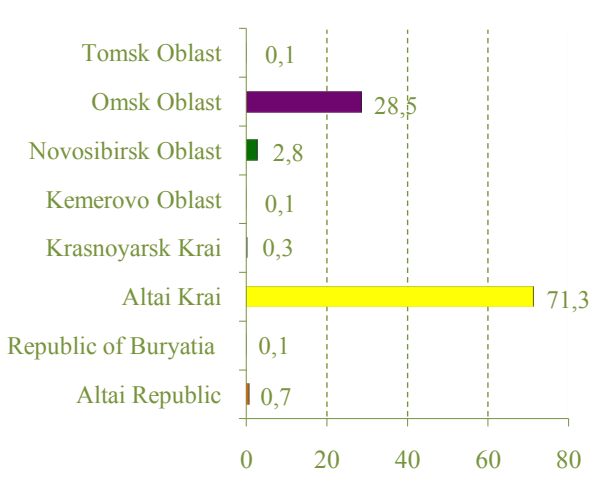

Fig. 12. The structure of production of cheese and cheese products in the regions of the SFD, thousand tons

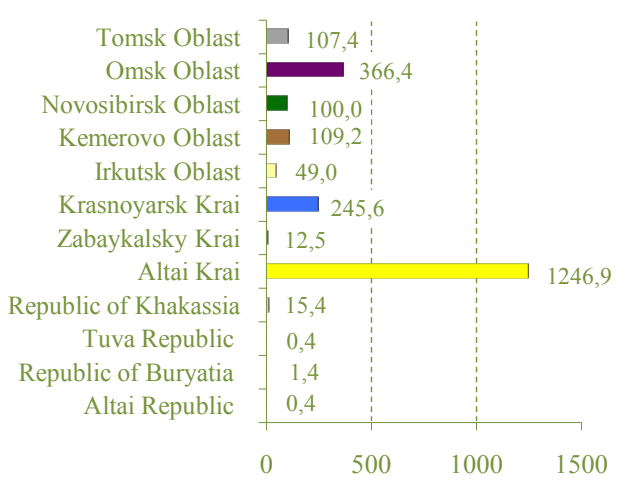

Fig. 14. The structure of production of flour from cereal grain, vegetable and plant crops, and mixed vegetables in the regions of the SFD, thousand tons

The analysis of the structure of potato production per capita in the context of the SFD regions showed that the SFD as a whole is ahead of the Russian Federation - $276 \mathrm{~kg}$ per capita, against $216 \mathrm{~kg}$ for the country. The production in the Krasnoyarsk Krai is $405 \mathrm{~kg}$ per capita, which exceeds the values for both the SFD and the country as a whole. Analysis of the structure of vegetables production per capita in the context of the regions of the SFD showed that the SFD as a whole is not ahead of the indicators for the Russian Federation - 79 kg per capita, versus $106 \mathrm{~kg}$ for the country. The production in the Krasnoyarsk Territory is $76 \mathrm{~kg}$ per capita, which does not exceed the value of both the SFD and the country as a whole. More clearly, the given 


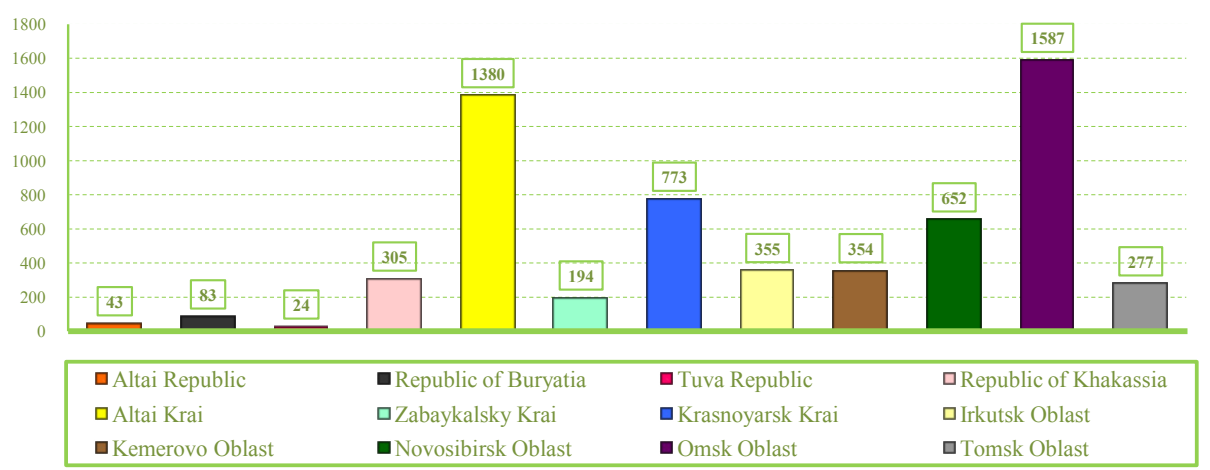

Fig. 15. The structure of grain and leguminous crops production in the regions of the SFD per capita, $\mathrm{kg}$

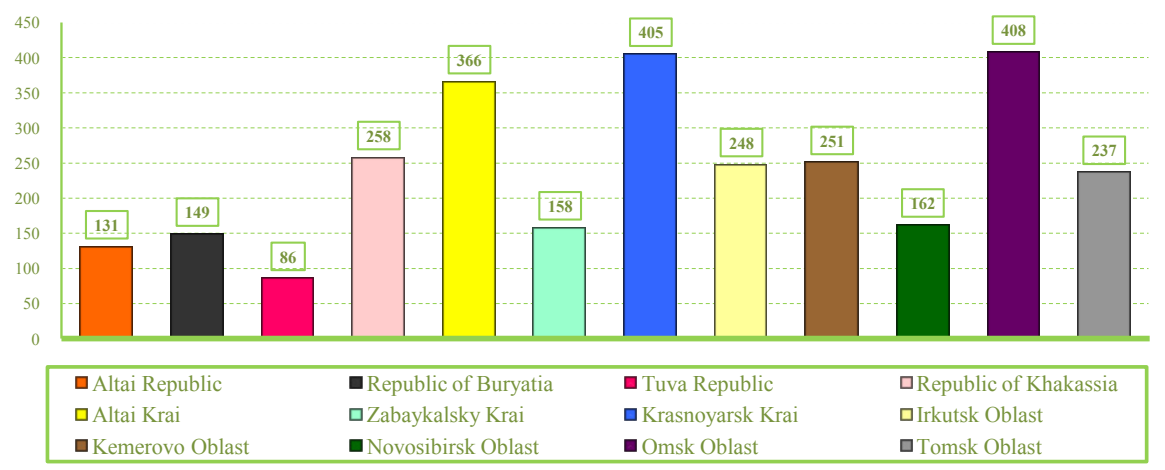

Fig. 16. The structure of potato production in the regions of the SFD per capita, $\mathrm{kg}$

structure in the context of regions will be graphically illustrated in Figures 15-17.

The largest production of grain and leguminous crops by the regions of the SFD per capita is in the Omsk Oblast - $1587 \mathrm{~kg}$, the Altai Krai - $1380 \mathrm{~kg}$ and the Krasnoyarsk Krai - 773 kg per capita (Fig. 15).

The largest potato production in the regions of the SFD per capita is represented in the Omsk Oblast - $408 \mathrm{~kg}$, Krasnoyarsk Krai - $405 \mathrm{~kg}$ and the Altai Krai - $366 \mathrm{~kg}$ per capita (Fig. 16).

The largest production of vegetables in the regions of the SFD per capita is in the Omsk Region - $127 \mathrm{~kg}$, in the Republic of Khakassia $116 \mathrm{~kg}$ and in the Altai Krai - $92 \mathrm{~kg}$ per capita (Fig. 17).

Further, the production of basic livestock products per capita in the context of the SFD regions will be analyzed.
The analysis of the structure of production of the main livestock products per capita in the context of the regions of the SFD showed that in production of livestock and meat for slaughter in the SFD is behind the indicators in the Russian Federation - $60 \mathrm{~kg}$ per capita, versus $62 \mathrm{~kg}$ in the country. The production in the Krasnoyarsk Krai is $45 \mathrm{~kg}$ per capita, which is lower than the national average.

The analysis of the structure of milk production per capita in the context of the regions of the SFD showed that the SFD as a whole is ahead of the indicators of the Russian Federation $279 \mathrm{~kg}$ per capita, versus $211 \mathrm{~kg}$ in the country. The production in the Krasnoyarsk Krai is $254 \mathrm{~kg}$ per capita, which is above the national average. The analysis of the structure of egg production per capita in the context of the regions of the SFD showed that the SFD as a whole is ahead 


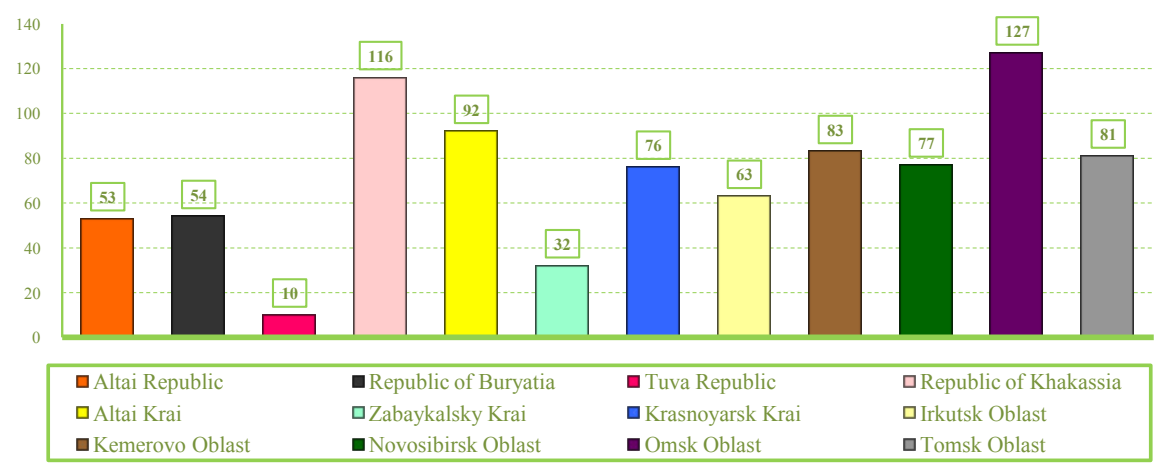

Fig. 17. The structure of vegetable production in the regions of the SFD per capita, $\mathrm{kg}$

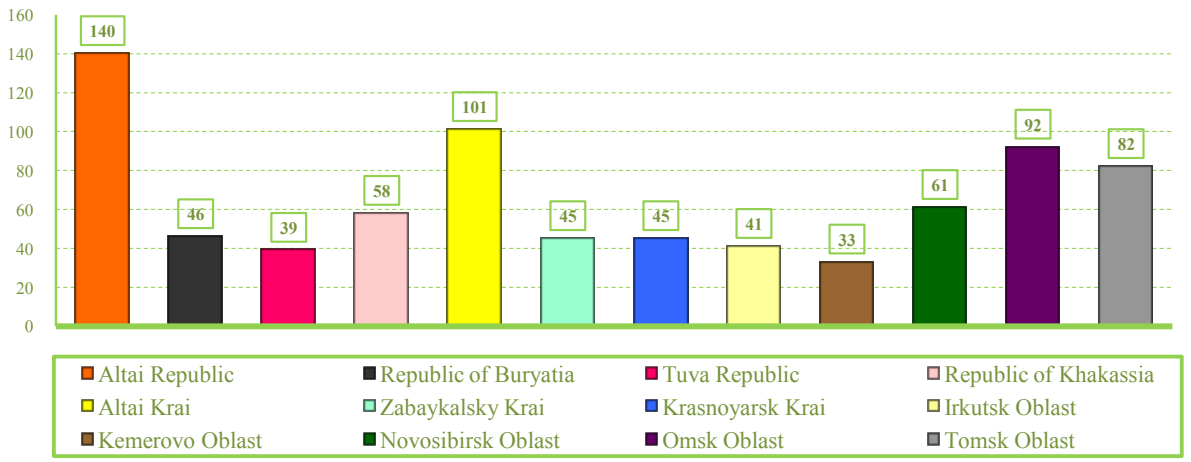

Fig. 18. The structure of production of livestock and poultry for slaughter in the regions of the SFD per capita, $\mathrm{kg}$

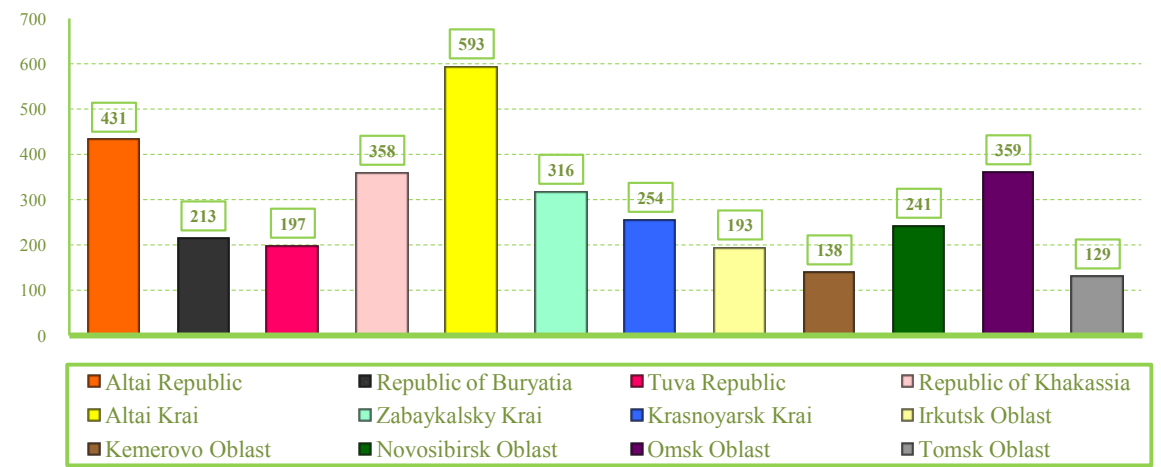

Fig 19. The structure of milk production in the regions of the SFD per capita, $\mathrm{kg}$

of the Russian Federation - 328 per capita, versus 287 in the country. The production in the Krasnoyarsk Krai is 277 units per capita, which does not exceed the values of both the SFD and the country as a whole. More clearly, the given structure in the context of regions is graphically illustrated in Figures 18-20.
The largest production of livestock and poultry for slaughter per capita in the regions of the SFD is in the Altai Republic - $140 \mathrm{~kg}$, the Altai Krai - $101 \mathrm{~kg}$ and the Omsk Oblast - $92 \mathrm{~kg}$ per capita (Fig. 18).

The largest production of milk per capita in the regions of the SFD is in the Altai Krai - 593 


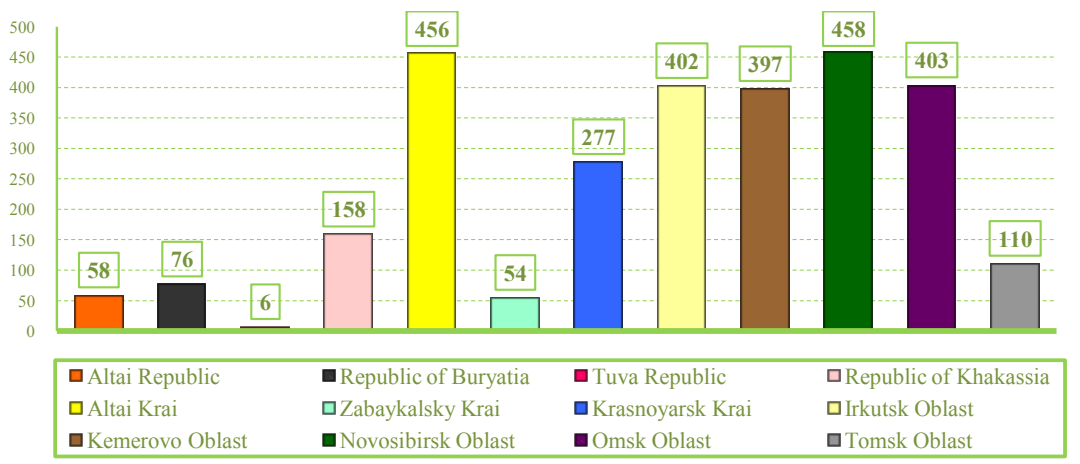

Fig. 20. The structure of eggs production in the regions of the SFD per capita, eggs

$\mathrm{kg}$, Omsk Oblast - $359 \mathrm{~kg}$ and the Republic of Khakassia - $358 \mathrm{~kg}$ per capita (Fig. 19).

The largest production of eggs per capita in the SFD is represented in the Novosibirsk Oblast - 458 eggs, the Altai Krai - 456 eggs and the Omsk Oblast - 403 eggs per capita (Fig. 20).

Thus, the development of production and processing in the agro-industrial sector of the regions of Siberia forms a significant value from the total volume of the country. In many ways Siberia supplies itself and neighboring regions with agricultural products, which allows to develop this economy sector steadily, despite economic difficulties, specific features of this market, the availability of imposed sanctions on a number of food products and other factors that determine development of the agro-industrial complex.

\section{References}

Agropromyshlennyi kompleks Sibirskogo federal'nogo okruga [Agro-Industrial Complex of the Siberian Federal District] (2010-2014). Barnaul, Altaikraistat, 156 p.

Agropromyshlennyi kompleks Sibirskogo federal'nogo okruga [Agro-Industrial Complex of the Siberian Federal District] (2006-2010). Barnaul, Altaikraistat, 140 p.

Regiony Rossii. Sotsial'no-ekonomicheskie pokazateli [The Regions of Russia. Socio-Economic Indicators] (2016). Moscow, Rosstat, 1326 p.

Rossiiskii statisticheskii ezhegodnik [Russian Statistical Yearbook] (2016). Moscow, Rosstat, $725 \mathrm{p}$.

Sotsial'no-ekonomicheskii monitoring sub'ektov Sibirskogo federal'nogo okruga: statisticheskii biulleten' [Socio-Economic Monitoring of the Regions of the Siberian Federal District: Statistical Bulletin] (2017). Novosibirsk, Territorial Body of Federal State Statistics Service in Novosibirsk Oblast, $151 \mathrm{p}$.

Sotsial'no-ekonomicheskoe polozhenie Rossii [The Socio-Economic Situation in Russia in] (2016). Moscow, Rosstat, $371 \mathrm{p}$.

Sotsial'no-ekonomicheskoe polozhenie Sibirskogo federal'nogo okruga v 2016 godu [SocioEconomic Situation of Siberian Federal District in 2016]. Moscow, Rosstat, 83 p. 


\title{
Потенциал производства агропромышленного комплекса \\ Сибирского федерального округа - \\ основа развития рынка продовольствия региона
}

\author{
Ю.Ю. Суслова, А.В. Волошин \\ Сибирский федеральный университет \\ Россия, 660041, Красноярск, пр. Свободный, 79
}

В данной статье проводится анализ производства основных видов продукции сельского хозяйства по регионам Сибирского федерального округа. В частности, проводится анализ структуры посевных площцдей зерновых культур, в т.ч. пшеницы, масличных культур, в т.ч. подсолнечника, овощей открытого грунта, картофеля, в хозяйствах всех категорий по регионам федерального округа. Отдельно анализируется структура поголовья крупного рогатого скота, прочзводства мяса, птицьь, масла сливочного, сыров, молока, яйца, муки и круп различных видов.

Также проводится исследование производства продукичи сельского хозяйства в расчете на душу населения по указанным выше видам продукиии растениеводства и животноводства, выявляются основные тенденции и закономерности в продуктовом балансе и структуре производства и переработки по регионам Сибирского федерального округа.

Ключевые слова: сельское хозяйство, агропромышленный комплекс, производство и переработка сельскохозяйственной продукции, потребность населения в продукции растениеводства и животноводства.

Научная специальность: 08.00.00 - экономические науки. 